Indonesian Journal of Islamic Psychology

Volume 1. Number 1, Juni 2019. (p-ISSN: 2685-1482)

website: http://e-journal.iainsalatiga.ac.id/index.php/ijip/index

\title{
Model Komunikasi Pendidikan Seksualitas Orang Tua Pada Remaja
}

\section{Widayati Lestari}

Institut Agama Islam Negeri Salatiga, Indonesia

widayatilestari82@gmail.com

\section{Abstract}

This study aimed at describing how the communication model of parental sexuality in adolescents. The method used was qualitative in the form of case studies. The results of this study explained that (1) Parental understanding of sexuality includes biological and physical, psychological, cultural and moral dimensions as well as social dimensions. (2) Sexuality education materials included gender differences, social ethics, responsibilities, and sexuality. (3) Parental communication models in sexuality education could be carried out without special time, by utilizing momentum, so that intimacy was established. (5) The child's response to parental communication style was positive when the atmosphere was conducive, and vice versa.

Keywords: Models, Communication, Sexuality Education and parents

\begin{abstract}
Abstrak
Penelitian ini bertujuan untuk mendeskripsikan bagaimana model komunikasi seksualitas orangtua pada remaja. Metode yang digunakan adalah kualitatif dalam bentuk studi kasus. Hasil penelitian ini menjelaskan bahwa (1) Pemahaman orang tua terhadap terhadap seksualitas meliputi dimensi biologis dan fisik, psikologis, kultural dan moral serta dimensi sosial. (2) Materi pendidikan seksualitas meliputi perbedaan gender, etika pergaulan, tanggung jawab, dan penyakit seksualitas. (3) Model komunikasi orang tua dalam pendidikan seksualitas dapat dilakukan dengan tanpa ada waktu khusus, dengan memanfaatkan momentum, sehingga terjalin keakraban. (5) Respon anak terhadap gaya komunikasi orangtua adalah positif saat suasana kondusif, dan sebaliknya.
\end{abstract}

Kata Kunci: Model, Komunikasi, Pendidikan Seksualitas dan orang tua 


\section{Pendahuluan}

Maraknya perilaku seksual remaja saat ini sudah semakin memprihatinkan. Perkembangan zaman rangsangan dari lingkungan seperti film, TV, VCD tentang perilaku seksual serta faktor gizi menyebabkan remaja sekarang lebih cepat perkembangan seksualnya karena hormon seksual muncul lebih awal.

Masa remaja merupakan masa transisi antara masa anak dan dewasa. Menurut Word Health Organization (WHO) remaja adalah penduduk dalam masa rentang usia 10-19 tahun. Pada masa rentang remaja banyak sekali perubahan-perubahan yang dialami remaja, baik itu perubahan biologis, kognitif maupun sosial. Perubahan fisik remaja juga begitu pesat, misalnya saja pada karakteristik seksualnya seperti pembesaran buah dada, perkembangan pinggang untuk anak perempuan, sedangkan untuk anak laki-laki tumnuhnya jenggot kumis serta perubahan suara yang semakin mendalam, Santrack, (2013).

Hasrat perilaku seksual diekspresikan dalam bentuk perilaku seksual mulai dari saling lirik, berpegangan tangan, mencium, memeluk, saling menggesek alat kelamin bahkan berhubungan seksual, Euis (2017)

Survey Demografi dan Kesehatan Indonesia (SDKI) Tahun 2012 mengenai kesehatan reproduksi remaja, menunjukkan bahwa secara nasional terdapat peningkatan angka remaja yang pernah melakukan hubungan seksual pranikah berdasarkan hasil survey SDKI 2012 KRR diperoleh data bahwa sekitar 9,3\% atau sekitar 3,7 juta remaja menyatakan pernah melakukan hubungan seksual pranikah. Sedangkan hasil SKEEI 2017 hanya sekitar 7\% atau 3 juta remaja (SDKI kemenkes 2012). 
Widayati Lestari

Berdasarkan data dari Pusat Informasi dan Layanan Remaja (PILAR) Jawa Tengah Tahun 2015, pada tahun 2011 tercatat 2.967 remaja yang berkonsultasi ke PILAR dimana sebanyak 821 remaja berkonsultasi tentang permasalahan kesehatan reproduksi dan terdapat 79 kasus tentang kehamilan tidak diinginkan (KTD) sementara tahun 2012 terdapat 63 kasus KTD pada remaja usia termuda 12 tahun. Dan pada tahun 2013 terdapat 64 kasus KTD, 26 kasus terjadi di Semarang (PILAR PKBI Jateng 2015).

Hal tersebut menunjukkan bahwa perilaku seksual remaja saat berpacaran memiliki pengaruh besar pada kasus kehamilan yang tidak diinginkan (KTD) dan berdampak pada remaja untuk melakukan aborsi. Data dari PKBI Jateng tahun 2014, menyebutkan hal tersebut dengan perincian 67 kasus KTD. Sebagian besar dari mereka berstatus pelajar yang membuat mereka memilih melakukan aborsi karena ingin melanjutkan sekolahnya (PILAR PKBI Jateng, 2015)

Sudiyanto (2014) sikap yang ditimbulkan oleh remaja terkadang menunjukkan perbedaan antara remaja putri dan remaja putra, perkembangan teknologi yang semakin pesat, maka informasi yang salah tentang seksual mudah sekali didapatkan oleh para remaja, sehingga media massa dan segala hal yang bersifat prognosis akan menguasai pikiran remaja yang kurang kuat dalam menahan pikiran emosinya. Sikap remaja yang lebih tertarik untuk mencari sendiri informasi mengenai seks membuat remaja rawan berperilaku seks pranikah. Remaja lebih tertarik untuk mencari segala informasi yang berhubungan dengan seksualitas di internet.

Idealnya, pendidikan seks terbaik adalah yang diberikan oleh orang tua sebagai pendidik utama. Tetapi sayangnya, di Indonesia tidak 
semua orang tua mau terbuka terhadap anak dalam membicarakan permasalahan seksual (Adnin ,2008).

Penelitian yang dilakukan oleh Wiendijarti (2011:44) mengenai komunikasi interpersonal orang tua dan anak dalam pendidikan seksual di SMU Yogyakarta kelas XI yang berjumlah 50 orang menunjukkan bahwa mereka mendambakan untuk memperoleh informasi tentang seks dari orang tua sendiri.

Penelitian selanjutnya dilakukan oleh Euis Nurhayati (2017) mengenai "pengaruh komunikasi internasional orangtua tentang pendidikan seks terhadap perilaku seksual remaja di kelurahan Tatura Utara kecamatan Palu Selatan kota Palu. Dengan jumlah remaja 94 orang, menunjukkan bahwa komunikasi personal memiliki pengaruh signifikan terhadap perilaku seks remaja baik secara parsial maupun simultan, dimana semakin baik komunikasi interpersonal, maka besar peluang remaja untuk terhindar dari perilakngan memperhatikan minat pada seks dalam diri anak maka pendidikan seksual perlu diberikan kepada anak karena pendidikan seks yang bersumber dari orang tua lebih menjamin proses kesinambungan berbeda-beda dengan informasi seksualitas yang diperoleh dari luar yang seringkali tidak dapat dipertanggungjawabkan kebenarannya dan mungkin anak hanya akan mendapat informasi secara parsial.

Dari latar belakang masalah di atas maka yang menjadi fokus permasalahan adalah bagaimana model komunikasi seksualitas orangtua pada remaja. Adapun subyek penelitian ini adalah orangtua di Salatiga yang memiliki anak remaja. 


\section{Tujuan Pendidikan Seks}

Pendidikan seks yaitu memberikan pengetahuan tentang perubahan biologis, psikologis dan psikososial sebagai akibat pertumbuhan dan perkembangan manusia atau sebuah pendidikan untuk memberikan pengetahuan tentang fungsi organ reproduksi dengan menanamkan moral, etika serta komitmen agama agar tidak terjadi "penyalahgunaan" organ reproduksi tersebut (Surtiretna, 2010).

Menurut Ulwan (2010) pendidikan seks adalah upaya pengajaran, penyadaran dan penerangan tentang masalah-masalah yang berkenaan dengan naluri seks dan perkawinan. Hal itu dimaksudkan agar jika anak telah tumbuh menjadi seorang pemuda dan dapat memahami unsur-unsur kehidupan, ia telah mengetahui masalah-masalah yang diharamkan dan dihalalkan. Lebih jauh lagi, ia bahkan mampu menerapkan tingkah laku Islami sebagai akhlak dan kebiasaan hidup, serta tidak dperbudak syahwat dan mempraktekkan cara-cara hedonisme.

Oleh sebab itu dalam pendidikan seks dapat dimaknai sebagai upaya untuk memberikan pengetahuan tentang fungsi organ tubuh yang berkaitan dengan seksual sekaligus mengarahkan agar menyalurkan fungsi seksualnya tersebut dengan baik dan benar.

Sedangkan sebagaimana dijelaskan Lilik Sriyanti (2008) ada beberapa tujuan pendidikan seksual pada remaja diantaranya: (1) Agar remaja mendapatkan pengetahuan yang benar, jelas dan akurat tentang kehidupan seksual seperti organ reproduksi beserta fungsi dan perawatannya, penyakit menular seksual (PMS), perilaku seksual sehat dan sebagainya. (2) Agar remaja bisa mengelola dorongan seksualnya dengan tepat. (3) Berperilaku sehat berkaitan dengan kehidupan seksualnya (dapat merawat dan menjaganya). (4) Dapat menjalankan 
hukum agama dengan benar berkaitan dengan kehidupan seksualnya.

(5) Tidak terjerumus dalam pergaulan bebas yang menyalahgunakan kehidupan seksualnya. (6) Dapat menghindari perilaku seksual menyimpang seperti kebiasaan masturbasi atau onani, sodomi, incest (hubungan seksual dengan anggota keluarga). (7) Terhindar dari perbuatan maksiat atau zina.

Jadi pendidikan seks adalah cara pengajaran atau pendidikan yang berhubungan dengan seks serta dorongan seksual dan fungsi reproduksi agar tidak terjadi penyalahgunaan fungsi reproduksi. Tujuan pendidikan seksual adalah membentuk sikap emosional yang sehat terhadap masalah seksual dan membimbing agar memiliki jiwa tanggungjawab terhadap kehidupan seksualnya.

\section{Tahapan-tahapan Pendidikan Seks}

Ada beberapa tahapan pendidikan seks menurut Ulwan (2010:1) diantaranya: 0 Fase pertama, usia 7-10 tahun biasanya disebut masa tamyiz (masa pra-pubertas). Pada masa ini anak diberikan pendidikan tentang etika minta izin dan memandang sesuatu. (2) Fase kedua, usia 10-14 tahun, biasa disebut masa murahaqah. Pada masa ini anak dihindarkan dari rangsangan seksual. (3) Fase ketiga yaitu usia 15-16 tahun disebut fase baligh. Pada maa ini diajarkan bagaimana saat haidh dan mengalami mimpi basah. (4) Fase keempat disebut sebagai fase pemuda. Dijelaskan bagaimana mengelola seksualitas saat ia belum mampu menikah.

\section{Karakteristik Pendidikan Seksual}

Menurut Gunarsa (2012) beberapa hal penting yang harus diperhatikan dalam memberikan pendidikan seksual adalah: (1) Cara 
Widayati Lestari

penyampaian harus wajar dan sederhana, jangan terlihat ragu-ragu atau malu. (2) Isi uraian yang disampaikan harus obyektif, namun jangan menerangkan yang tidak-tidak. (3) Dangkal atau mendalamnya isi uraiannya harus disesuaikan dengan kebutuhan dan dengan tahap perkembangan anak. (4) Pendidikan seksual harus diberikan secara pribadi karena luas sempitnya pengetahuan dengan cepat lambatnya tahap-tahap perkembangan tidak sama bagi setiap anak. (5) Usahakan diulang-ulang (repetitif) untuk mengetahui seberapa jauh sesuatu dapat diserap oleh anak juga untuk memperkuat (reinforcement) apa yang telah diketahui agar benar-benar menjadi bagian dari pengetahuannya.

\section{Perkembangan Seksual Remaja}

Masa remaja adalah masa peralihan dari anak-anak ke dewasa yang pada umumnya dimulai dari usia 12 atau 13 tahun dan berakhir pada usia akhir belasan tahun atau awal 20 tahun (Papalia, 2011).

Sedangkan menurut Desmita (2010) menjelaskan bahwa remaja berasal dari bahasa Latin puberty atau pubertas dan adolescense yang artinya masa muda antara 17 dan 30 . Jadi kesimpulannya remaja adalah masa transisi dari anak-anak menuju dewasa dimulai usia 12 tahun sampai usia 25 tahun.

Hurlock dalam Lilik (2010) mengemukakan tugas-tugas perkembangan remaja dalam hal seksualitas secara lengkap meliputi: (1) Memperoleh pengetahuan seksual yang benar.

Mengembangkan sikap yang menyenangkan terhadap lawan jenis. (3) Mengembangkan hubungan dengan lawan jenis yang matang. (4) Menetapkan nilai-nilai yang menjami adanya keputusan yang 
bijaksanaa di dalam pemilihan pasangan hidup. (5) Belajar mengekspresikan cinta. (6) Belajar memainkan peran jenis.

Menurut Sarwono (2011) perkembangan seksualitas remaja ditandai dengan hal-hal berikut ini: (1) Adanya minat untuk mempelajari tubuh sendiri, respon seksual dan kebutuhannya. (2) Mempelajari hubungan seksual dan interaksinya dengan lawan jenis berupa keterikatan hubungan, percintaan dan komitmen.

\section{Komunikasi Interpersonal}

Definisi konseptual komunikasi adalah usaha untuk menyampaikan pesan, informasi, pikiran, gagasan dan pendapat yang dilakukan oleh seseorang atau kelompok orang lain. Komunikasi merupakan proses penyampaian pesan oleh seseorang kepada orang lain untuk memberitahu, mengubah sikap, pendapat atau perilaku baik langsung secara lisan maupun tak langsung melalui media. Dalam komunikasi ini memerlukan adanya hubungan timbal balik antara penyampai pesan dan penerimanya yaitu komunikator dan komunikan.

Menurut Carl I. Hovland, ilmu komunikasi adalah upaya yang sistematis untuk merumuskan secara tegas asas-asas penyampaian informasi serta pembentukan pendapat dan sikap. Secara garis besar dapat disimpulkan bahwa komunikasi adalah penyampaian informasi dan pengertian seseorang terhadap orang lain Ngalimun (2018:1).

\section{Karakteristik komunikasi interpersonal}

Ada beberapa karakteristik komunikasi interpersonal: (1) Komunikasi interpersonal dimulai dengan diri pribadi (self). (2) Komunikasi interpersonal bersifat transaksional. (3) Komunikasi interpersonal menyangkut aspek isi pesan dan hubungan antarpribadi. 
Widayati Lestari

(4) Komunikasi interpersonal mensyaratkan adanya kedekatan fisik antar pihak-pihak yang berkomunikasi. (5) Komunikasi interpersonal menempatkan kedua belah pihak yang berkomunikasi saling tergantung satu sama lainnya (interdepensi). (6) Komunikasi interpersonal tidak dapat diubah maupun diulang (Ngalimun, 2018).

\section{Metodologi Penelitian}

Penelitian ini menggunakan metode kualifikatif dengan pendekatan yang digunakan adalah pendekatan studi kasus yaitu srategi penelitian dimana di dalamnya peneliti menyelidiki secara cermat suatu pogram, peristiwa, aktivitas, proses atau sekelompok individu. Penelitian ini dilakukan di Kota Salatiga dengan sampel tiga pasang keluarga dan tiga anak. Dari ketiga keluarga tersebut telah melakukan Pendidikan seksual. Kasus-kasus dibatasi oleh waktu dan aktivitas, dan peneliti mengumpulkan informasi secara lengkap dengan menggunakan berbagai prosedur pengumpulan data berdasar waktu yang telah ditentukan (Stake dalam Creswell, 2010).

Tekhnik pengumpulan data dengan wawancara, yang dimaksudkan untuk mengungkap peran orang tua dalam pendidikan seks bagi remaja. Wawancara yang dilakukan dengan tak terstruktur, kemudian membuat transkript (Cresswell, 2010). Esterberg, dalam (Sugiyono, 2011) menjelaskan bahwa wawancara tak struktur mengandung makna dimana peneliti tidak menggunakan pedoman wawancara yang telah tersusun secara sistematis dan lengkap untuk mengumpulkan data. Pedoman yang digunakan hanya berupa garisgaris besar saja. Dalam wawancara ini peneliti belum mengetahui secara pasti data apa yang akan diperoleh, sehingga peneliti lebh banyak mendengarkan apa yang diceritakan oleh responden. 


\section{Hasil Penelitian dan Pembahasan}

Model komunikasi orangtua dalam pendidikan seksualitas remaja Berdasarkan hasil penelitian di lapangan didapatkan deskripsi atau gambaran mengenai pemahaman orangtua terhadap seksualitas, model komunuikai orangtua dalam penyampaian pendidikan seksualitas, materi yang disampaikan, dan respon remaja terhadap pendidikan seksualitas dari orangtua.

Pemahaman terhadap apa yang akan diajarkan menjadi faktor besar dalam penentu keberhasilan. Dari hasil penelitian didapatkan bahwa pengertian seks dapat dikategorikan menjadi: (1) seks berkaitan dengan biologis dan fisik, (2) seks berkaitan dengan hal psikologis, (3) seks berkaitan dengan kultural dan moral, (4) seks berkaitan dengan persoalan sosial.

Seks berkaitan juga dengan masalah biologis dan fisik terungkap dalam wawancara dengan salah satu subyek.

"(senyum) waduh saya harus belajar dulu ini... (senyum). Ya... e... berbicara tentang seks berarti berbicara mengenali satu bahwa: satu, mengetahui jenis kelamin laki-laki, dua tahapan selanjutnya mengenalkan pubertas. Kalau saya terbantu dengan pelajaran Penjaskes, habis itu sebenarnya itu kan ada bab tentang mengetahui kesehatan pribadi juga disitu ada tentang organ seks itu dan yang paling penting tentang seks itu ketika anak itu sekolah di sekolah Islam, selain itu kita juga berkomunikasi tentang apa saja kadar perkembangan atas perubahan tubuh yang ingin diketahui anak. InshaAlloh sesuai dengan tahapan anak serta membuka pikiran mereka tentang seks. (W1, POS, 3-18)"

Seks juga dipandang sebagai sesuatu yang berhubungan dengan persoalan psikologis. Hal ini sesuai diungkap dalam wawancara "Sama... (Senyum) dengan bapak, hanya saja memang butuh apa ya... istilahnya sek itu sebuah fitroh kebutuhan penting manusia namun butuh 
Widayati Lestari

penjelasan. Penjelasan terkait organ tubuh itu sendiri sehingga saat sudah tiba saatnya difungsikan itu tidak akan menyimpang karena sudah tahu bagaimana menempatkan yang tepat (W3, POS, 7-14)"

Seks juga merupakan hal yang terkait dengan kultural dan moral. Hal tersebut terungkap dengan wawancara dengan salah satu subyek.

“Waduh sama, tapi saya coba. Ya, menurut saya yang namanya seks itu sesuatu yang penting dalam kehidupan manusia sehingga harus ditangkap secara proporsional dan perlu disampaikan kepada anak sehingga dari awal ya seperti sudah punya bekal sehingga, e... e... tidak ada yang disalahgunakan. Dan seks merupakan sesuatu yang memiliki peran dan harus diangkat dalam kehidupan dan disampaikan sehingga anak sudah punya bekal dan tidak disalahgunakan itu aja. (W2, POS, 19-30)"

Seks juga berkaitan dengan masalah sosial, hal tersebut dapat dilihat dari kutipan wawancara pada salah satu subjek.

"Waduh sama, tapi saya coba. Ya, menurut saya yang namanya seks itu sesuatu yang penting dalam kehidupan manusia sehingga harus ditangkap secara proporsional dan perlu disampaikan kepada anak sehingga dari awal ya seperti sudah punya bekal sehingga, e... e... tidak ada yang disalahgunakan. Dan seks merupakan sesuatu yang memiliki peran dan harus diangkat dalam kehidupan dan disampaikan sehingga anak sudah punya bekal dan tidak disalahgunakan itu aja. (W2, POS, 19-30)"

Seks terkait persoalan biologis dan fisik tidak hanya sekedar menjelaskan tentang alat kelamin saja, namun terkait dengan bagian tubuh dan fungsi-fungsinya serta pengenalan organ reproduksi. Perbedaan jenis kelamin berarti menjelaskan tentang perbedaan alat kelamin antara laki-laki dan perempuan agar anak mengerti dan mengenal dirinya.

Mengenal bagian tubuh dan fungsi-fungsinya berarti orang tua menjelaskan tentang bagian tubuh dan fungsi-fungsinya terutama yang terkait dengan masalah seksual. Apabila anak telah mengenal tentang 
jenis kelaminnya sendiri maka kenalkan dengan fungsi-fungsinya semakin orang tua memahami hal ini maka akan semakin tumbuh kesadaran dan tanggungjawabnya karena orangtua adalah mewakili jenis pria dan wanita. Selain itu, seks berarti pengenalan organ reproduksi dimana laki-laki dan perempuan memiliki organ reproduksi sendiri yang berfungsi untuk melanjutkan keturunannya dan difungsikan secara tepat dan benar. Pemahaman orang tua terhadap seks yang benar inilah yang akan mempercepat proses pendidikan selanjutnya.

\section{Model Komunikasi Orangtua dalam Pendidikan Seksualitas pada remaja}

Cara mengkomunikasikan seks pada anak salah satu jenis komunikasi yang sering dijumpai di masyarakat adalah jenis komunikasi interpersonal. Komunikasi ini tidak hanya sebatas pesan saja. Adanya umpan balik merupakan tanda bahwa kominikasi akan efektif jika memenuhi komponen-komponen tertentu.

Menurut Widjaya (2002), unsur-unsur komunikasi meliputi communicator (pengirim pesan), communicate (saluran atau media), Communicant (Penerima pesan) dan effect hasil).

Berdasarkan analisis data ditemukan bahwa tidak ada waktu khusus dalam penyampaian pendidikan seks orang tua pada anak sesuai dengan pernyataan semua subyek karena memang waktu penyampaian bersifat fleksibel. Hal ini terungkap pada kutipan wawancara dengan subyek sebagai orang tua.

"Waktu kumpul setiap hari kita banyak waktu soalnya (ketawa) biasanya kita kumpul habis maghrib. Kalau ada perlu banget misal di sekolah dia merasa apa maka dia akan menelpon saya, "Mi, aku lagi gini...gini... begitu" (W1, KK, 130-135) 
Pendidikan seks juga disampaikan dengan memanfaatkan momentum. Seks berfungsi sebagai manifestasi Seksualitas individu dalam hubungannya dengan individu lain. Aspek ini meliputi pengaruh budaya, berpacaran, hubungan interpersonal dan semua hal tentang seks yang berhubungan dengan kebiasaan-kebiasaan yang dipelajari oleh individu di dalam lingkungannya (Brues dan Greenberg, 1981). Termasuk budaya yang mempengaruhi seks dapat dilihat pada iklan, film, radio, televisi, buku-buku, majalah atau peristiwa langsung yang dapat mempengaruhi pikiran seseorang. Maka, saat ada peristiwa langsung maka berikan pendidikan seks karena remaja akan lebih mengingat pendidikan yang diberikan saat berhadapan dengan peristiwa langsung. Dengan melihat peristiwa langsung maka orang tua juga dapat mengevaluasi pemahaman pendidikan seks yang telah diberikan sebelumnya dan anak juga antusias. Hal ini terungkap dalam wawancara dengan salah satu subyek.

"Peristiwa apa gitu ya...e.. ya anaknya... alhamdulillah anak-anak itu saya terbantu sekali dengan anak karena anak-anak kan di sekolah Islam dan juga saya jelaskan bagaimana ghudhul bashor (menahan pandangan terhadap lawan jenis) saat lihat TV berpakaiannya membuka aurot langsung disitulah saya memberikan pendidikan seks ya sambil memantapkan tentang apaapa yang anak itu belum paham dan anak-anak akan bercerita tentang bagaimana hukum pacaran dan sebagainya. (W1, KK, 138149)"

"Nambahi dikit saat peristiwa anak saya mimpi basah terus kami langsung memanggil dan minta diceritakan pengalaman pertamanya. Terus ketiga anak saya tanya semua tentang mimpi basah kami akhirnya memberikan pendidikan secara detail karena saat itu anak sedang antusias. (W1, KK, 161-167)" 
Dengan ada moment tepat maka anak akan merasa kebutuhannya terpenuhi. Menurut (Latif, 2013) anak akan dapat belajar dengan baik jika kebutuhannya terpenuhi. Jika moment tepat anak akan merasa butuh dan akan menggali lebih banyak. Komunikasi orangtua dan anak dikatakan efektif atau berkualitas bila kedua belah pihak saling dekat, saling menyukai dan komunikasi keduanya merupakan hal yang menyenangkan.

Pendidikan seks juga harus disampaikan dengan lengkap, Sarlito (2000) secara umum pendidikan seksual adalah suatu informasi mengenai persoalan seksualitas manusia yang jelas dan benar yang meliputi proses terjadinya pembuahan, kehamilan sampai kelahiran, tingkah laku seksual hubungan seksual dan aspek-aspek kesehatan kejiwaan dan kemasyarakatan. Jadi, idealnya memang pendidikan seksual diberikan dengan dengan lengkap agar tidak terjadi penyimpangan seksual.

Meningkatnya minat terhadap seksual harus dapat diimbangi orangtua dengan memberikan informasi lengkap dan tepat. Remaja memiliki sifat ingin tahu dan keinginan kuat untuk mencoba. Jiwa petualangannya sangat kuat termasuk petualangan di dalam hubungan percintaan.

Sangat memungkinkan remaja melakukan berbagai eksperimen seputar kehidupan seksual, untuk memenuhi rasa ingin tahunya serta terdorong oleh hasrat ingin mencoba yang besar. Kondisi ini jika dibiarkan akan membahayakan kehidupan remaja.

Pendidikan seks juga dikomunikasikan dengan anak dimulai sejak balita. Singgih D Gunarsa (1995) berpendapat bahwa dangkal atau dalamnya isi uraian pendidikan seks harus disesuaikan dengan kebutuhan dan dengan tahap perkembangan anak. Artinya 
Widayati Lestari

keberhasilan dan efektifitas komunikasi pendidikan seksualitas antara orangtua dan anak sangat tergantung dengan tahapan penyampaian materi ,yakni dimulai dari usia balita dan bertahap sampai memasuki tahapan berikutnya.Komunikasi adalah proses transaksi berkelanjutan yang selektif,sistematis dan unik yang membuat mampu merefleksikan dan mampu membangun pengetahuan bersama orang kain.Komunikasi interpersonal adalah proses berkelanjutan ,proses yang berlangsung terus menerus (mengalami perkembangan yang berarti )sejalan dengan tingkat perkembangan remaja (Erni,2017).Penyampaian pendidikan seks sebaiknya juga disampaikan dengan berbagi agar semakin dekat hubungan dengan anak. Hal ini terungkap dalam wawancara dengan beberapa subyek.

"Kalau saya lebih banyak dengan diskusi. Saat mendapat info baru karena anak-anak cerita tadi saya itu. Kalau apa-apa harus ada dasarnya maka kadang saya membawa buktinya d buku atau saya bukakan diinternet bisa dibuka via hp jadi lebih mudah. (W5, KK, 146-151)" "Diskusi dengan tanpa adanya unsur tekanan (W6, KK, 64-65)"

Penyampaian pendidikan seks juga dilakukan dengan memposisikan anak sebagai sahabat. Hal ini terungkap dalam wawancara dengan salah satu subyek. Dimana dalam melakukan Pendidikan seks tersebut dilakukan sebagaimana seperti teman sendiri. Pendidikan seks disampaikan tanpa harus diawali dengan sebuah peristiwa. Hal tersebut karena orang tua menyadari bahwa pada masa sekarang ini pendidikan seks memang harus diberikan kepada anak. Menjadi kewajiban orantua untuk membantu remaja memenuhi kebutuhan akan rasa keingintahuan mereka agar mendapat ketenangan dan kebahagiaan. 
Hal ini seperti yang terungkap pada kutipan wawancara dengan subyek sebagai orang tua.

"Kalau saya ya tidak mesti harus ada peristiwa bu, karena memang anak harus dibekali tapi kadang juga pada saat nonton film dan ada yang harus dijelaskan. Ya disitulah momentnya kita jelaskan juga. (W5, KK, 89-93)".

Pendidikan seks juga disampaikan dengan menyesuaikan kebutuhan. Saat anak bertanya maka saat itulah anak sedang antusias. Secara alamiah anak memiliki rasa ingin tahu yang besar terhadap masalah seksualitas. Minat pada masalah seks ini berkembang dan mencapai puncak pada masa puber (Hurlock, 2000). Ketika anak bertanya maka berikan respon yang baik dan layani semua pertanyaan anak.

Interaksi yang terjalin dalam penyampaian pendidikan seks sebaiknya dalam suasana akrab. Dengan suasana akrab maka akan ada keterbukaan tanpa unsur tekanan. Pada saat itulah anak merasakan kenyamanan. Menurut Putra (2012) kondisi yang menyenangkan, aman, nyaman dan bebas dari rasa takut akan mempengaruhi sistim limbik pada otak anak yang akan berpengaruh pada serebrum yang mengandung neokorteks untuk berpikir anak. Disinilah peran orang tua menjadi sangat penting untuk memberikan pendidikan seks yang akan berperan banyak dalam kehidupan anak kelak.

\section{Materi Pendidikan Seksualitas}

Perbedaan jenis kelamin menjadi materi yang umum dan harus disampaikan perbedaan jenis kelamin meliputi juga organ reproduksi dan fungsinya, mainan yang seharusnya diberikan kepada masing- 
masing anak dengan jenis kelamin berbeda dan juga organ reproduksi dengan fungsi tertentu.

"Ya, seperti tadi perbedaan kelamin, aurot sesuai hadist, pergaulan dan lainnya. (W1, KK, 195-197)"

Etika pergaulan juga menjadi bagian yang harus dijelaskan dalam pendidikan seks (Ulwan, 2000). Pergaulan juga harus dijelaskan terutama tentang batasan-batasan pergaulan agar tidak terjadi penyimpangan seksual (Ulwan, 2000). Etika pergaulan menyangkut hal tidak tidur dalam satu selimut. Sebagaimana terungkap dalam wawancara dengan salah satu subyek

"Ya kami menjelaskan tentang perbedaan jenis kelamin, tidak tidur dengan selimut bersamaan, meminta ijin mengetuk pintu kamar orang tua diwaktu-waktu tertentu. Itu kita tanamkan sejak kecil. $Y a$, itu kita usahakan mungkin jauh dari sempurna tapi ya kita berusaha, juga tutup aurot, tidur dan juga memisahkan tempat jika menjelang remaja (W3, KK, 123-131)".

Meminta ijin juga pemisahan tempat tidur antara laki-laki dan perempuan (Ulwan, 2000). Keharusan meminta izin ini adalah dalam tiga keadaan: sebelum salat fajar, sebab saat itu orang-orang biasanya maih tidur, kedua, pada waktu siang, sebab ketika itu orang-orang biasanya menanggalkan pakaiannnya (beristirahat), ketiga setelah shalat Isya'. Sebab saat itu adalah saatnya tidur dan istirahat (Ulwan, 2000).

Selain itu juga materi tentang belajar bertanggung jawab yang harus dilakukan saat anak memasuki baligh juga harus diberikan ke anak sebagaimana dikutip dalam wawancara dengan salah satu subyek

"Ya, kamu sudah dewasa berarti ada hal yang harus kamu lakukan, ada yang tidak boleh, ada pembatasan pergaulan, ada kemandirian termasuk belajar berpenghasilan sekecil apapun, ada mainan 
khusus untuk perempuan dan mainan khusus untuk laki-laki. (W6, PT, 42-46)".

Penyalahgunaan seksual dan penyakit-penyakit seksual juga harus dimasukkan dalam materi pendidikan seks agar tidak terjadi banyak penyimpangan seksual. Hal tersebut terungkap dalam wawancara

"Kalau menurut saya yang penting bagaimana anak bisa paham dan tidak menyalahgunakan seks, sehingga anak tidak memperburuk citra orangtua, merusak masa depan anak dan yang lebih parah anak jika tidak paham tentang penyakit-penyakit yang akan diderita saat menyalahgunakan seks itu. Jadi menurut saya yang paling banyak diberikan ke anak adalah bagaimana agar anak dijelaskan tentang seks secara panjang lebar sehingga tidak menimbulkan penyimpangan-penyimpangan dalam masyarakat. (W2, KK, 177-188)".

Penyakit seksual diberikan anak agar anak memahami akibatakibat yang akan dihadapi saat ia melakukan tindakan-tindakan yang tidak sesuai dengan norma agama dan masyarakat, hal tersebut terungkap dalam wawancara

"Kalau menurut saya yang penting bagaimana anak bisa paham dan tidak menyalahgunakan seks, sehingga anak tidak memperburuk citra orangtua, merusak masa depan anak dan yang lebih parah anak jika tidak paham tentang penyakit-penyakit yang akan diderita saat menyalahgunakan seks itu. Jadi menurut saya yang paling banyak diberikan ke anak adalah bagaimana agar anak dijelaskan tentang seks secara panjang lebar sehingga tidak menimbulkan penyimpangan-penyimpangan dalam masyarakat. (W2, KK, 177-188)".

Tahapan pemberian seks meliputi perbedaan kelamin, tutup kamar mandi, tutup aurat, saat masih batita dan sebelum baligh. Ketika 
remaja materi seputar persolaan fisik, etika pergaulan dan pengetahuan seksual.

\section{Respon Anak Terhadap Pendidikan Seks}

Respon anak terhadap pendidikan seks yang diberikan orangtua juga mendukung cepatnya penyampaian informasi. Berdasarkan hasil penelitian respon anak didapat beberapa hasil. Anak respon positif karena kondusif dan anak respon negatif karena moment tidak tepat.

Anak respon positif karena kondusif dapat dilihat dalam wawancara pada salah satu subyek

"Ya antusias karena anak-anak selalu terbuka (W3, RPS, 169-170)".

Selain itu dari hasil penelitian didapatkan bahwa anak senang karena orang tua selalu peduli dengan anak sehingga anak pun antusias saat anak diajak berdiskusi tentang persoalan seksual.

"Anak senang karena kami memang ada apa-apa terbuka. Pernah anak pergi bilang mau mengerjakan $P R$ di rumah teman, karena pamit sampai jam kok belum pulang. Kami pun mencarinya meski mereka laki-laki, setidaknya kami menunjukkan kepedulian kami. (W1, RPS, 270-276)".

Peran komunikasi sangat penting dalam menyampaikan informasi mengenai pengetahuan seksualitas termasuk juga pemahaman akan moment yang tepat (Prihartini, 2002).

Adapun saat anak respon negatif dari hasil penelitian didapat berbagai hasil yakni karena anak sedang capek ataupun moment tidak tepat. Hal tersebut terungkap dalam wawancara

"Pernah juga, tapi mungkin karena momentnya tidak tepat. Capek ya tidak ada respon, ya tidak saya lanjutkan. Besok dilanjutkan di lain kesempatan. (W5, RPS, 162-165)" 
Keharusan memahami kondisi anak inilah yang harus dimiliki orang tua. Beberapa cara yang dilakukan antara lain dengan memberi jeda ataupun diajak berdiskusi di lain waktu sebagaimana terungkap dalam wawancara.

"Kami selama ini menyadari dan memahami karena remaja itu kan meletup-letup, masa puber jadi kalau anak lagi tidak respon dengan apa yang kami sampaikan, ya kami ajak diskusi lain waktu dan semua terselesaikan. (W2, RPS, 277-282)".

\section{Sikap Anak}

Sikap anak saat diberikan pendidikan sangat menentukan terhadap penerimaan ilmu yang diberikan. Dari hasil penelitian didapat bahwa sikap anak terhadap pendidikan seks adalah (1) anak menganggap orangtua peduli, (2) anak respon, (3) dan anak terbuka masalah seks dan anak menganggap orangtua peduli dengan anak saat memberikan pendidikan seks. Dilihat saat orangtua respon terhadap pertanyaan anak soal seks, ayah dan ibu memberikan pendidikan sejak kecil, orangtua mendampingi anak saat baligh dan anak senang jika orang tua mendampingi. Hal tersebut terdapat pada kutipan dengan salah satu subyek.

"Ya. kalau bapak ya paling jawab apa adanya. Kalau Ibu biasanya panjang kali lebar jadi tinggi (tertawa) jadi luas banget. (W3, STP, 29-31)".

Anak respon terhadap pendidikan seks ditandai dengan anak suka bertanya masalah seks, anak senang dengan pendidikan seks dari orang tua dan anak merasa orang tua memberikan pendidikan seks pada saat yang tepat. Hal tersebut dapat dilihat pada kutipan wawancara dengan salah satu subyek. 
"e...e... ya, kalau lihat $T V$, atau saat cerita atau naik motor trus pas liat orang pacaran. (W2, STP, 20-22)".

Anak juga terbuka masalah seks pada orangtua ditandai dengan anak bercerita masalah seks pada orangtua dan anak sering berbagi serta diskusi dengan orangtua tentang seks. Hal tersebut ada dalam kutipan wawancara dengan salah satu subyek.

"Ya cerita, takut kalau tidak (W2, STP, 49)"

\section{Sumber Pendidikan Seks Anak}

Sumber pendidikan seks anak dari hasil penelitian didapatkan data meliputi: (1) internet, (2) buku, (3) guru, (4) teman. Internet saat ini juga menjadi media yang sangat digemari dalam hal mencari informasi.

Media cetak atau buku juga salah satu media tempat anak remaja mencari informasi seksual sebagaimana dikutip dalam salah satu wawancara dengan salah satu subyek.

"Dari internet dan buku karena ingin tahu (W1, SPS, 47-48)"

Guru juga menjadi tempat bertanya masalah seksual, pengaruh media dalam kehidupan remaja telah diteliti oleh L'engle Brown dan Kenneavy (2006) berdasarkan penelitian terungkap bahwa remaja yang lebih banyak terpapar media dengan materi seksual dan mempersepsi adanya dukungan dari media terhadap perilaku seksual remaja melaporkan aktivitas seksual yang lebih tinggi dan memiliki intensi yang lebih tinggi untuk melakukan hubungan seksual di kemudian hari.

Untuk itulah peran dari orangtua dalam pendidikan seks sangat membantu remaja untuk memberikan informasi yang tepat tentang 
masalah seksual kepada remaja. Teman dekat juga menjadi tempat bertanya masalah seksual sebagaimana dalam kutipan wawancara.

"Dari guru, teman dan internet (W2, SPS, 56)"

Selain itu remaja ingin mengetahui masalah seksual karena penasaran, rasa ingin tahu serta bisa nyambung saat ngobrol dengan teman dan supaya tahu kalau ada tahu teman yang menyimpang.

"Kan ya penasaran, selain itu juga biar nyambung kalau ngobrol dengan teman, juga biar kalau ada teman menyimpang tahu. (W3, SPS, 75-77)".

Hawk (2006) mengidentifikasi tiga motivasi remaja untuk mengakses media yang bermateri seksual yakni kenikmatan fisik, rekasi dan keinginan mendapatkan pengetahuan.

Komunikasi pendidikan seksualitas tidak hanya bermanfaat untuk diri sang anak saja namun juga dapat bermanfaat sebagai sumber informasi bagi teman sebayanya dalam menjaga perilaku seksualitas sehingga mampu menjaga fitrah seksualitas yang ada pada dirinya.

\section{Simpulan}

Pemahaman orangtua terhadap seksualitas meliputi seks meliputi dimensi biologis dan fisik, psikologis, kultural dan moral, serta dimensi sosial. sejauh mana orangtua memahami seksualitas maka akan berdampak pada bagaimana orangtua memberikan informasi seputar pendidikan seksualitas pada remaja. Semakin luas orangtua memahami seksualitas maka akan semakin bagus dalam mengkomunikasikan pendidikan seksualitas pada anak. Sebaliknya jika orangtua memahami 
seksualitas hanya satu dimensi saja maka pendidikan seksualitas yang diberikan juga akan menjadi sempit.

Model komunikasi orangtua dalam pemberian pendidikan seksualitas remaja dapat dilakukan dengan tanpa ada waktu khusus, dengan memanfaatkan momentum, disampaikan dengan lengkap, serta dimulai sejak usia batita. Selain itu pendidikan seksualitas juga diberikan menyesuaikan dengan kebutuhan anak dan tanpa harus diawali dari sebuah peristiwa. Penyampaian disampaikan dengan berbagi dan interaksi terjalin dalam suasana akrab. Pemilihan waktu dan suasana yang tepat dalam pemberian informasi seksualitas pada remaja sangat berpengaruh terhadap bagaimana respon anak. Semakin tepat waktu dan suasana maka akan semakin bagus respon anak dalam menerima pendidikan seksualitas. Sebaliknya respon anak akan rendah ketika komunikasi seksualitas yang disampaikan tidak tepat waktu dan suasananya.

Materi pendidikan seks meliputi perbedaan jenis kelamin, etika pergaulan, belajar bertanggungjawab dan penyakit-penyakit seksual. Penyampaian materi dilakukan secara bertahap sesuai perkembangan anak. Saat masih batita dan menjelang baligh diberikan materi seputar perbedaan jenis kelamin dan etika pergaulan. Setelah materi diberikan materi tentang bagaimana belajar bertanggungjawab dan penyakitpenyakit seksual. Ayah lebih banyak menyampaikan materi seputar tanggung jawab seperti keharusan memberi nafkah bagi laki-laki dan juga materi seputar persoalan fitrah seksualitas anak laki-laki. Seperti persoalan mimpi basah dan hal-hal seputar seksualitas laki-laki. Sebaliknya ibu menyampaikan materi seputar fitrah perempuan seperti haid, nifas, etika pergaulan juga masalah persoalan kesehatan reproduksi. Selain itu latar belakang pendidikan orangtua juga 
berpengaruh dalam komunikasi pendidikan seksualitas untuk remaja. Orangtua dengan latar belakang pendidikan ilmu agama akan memberikan materi lebih mendalam terkait persoalan syari'at. Orangtua dengan latar belakang psikologi akan memberikan pendidikan seksualitas dengan persoalan psikologis. Orangtua dengan latar belakang kesehatan akan menjelaskan lebih mendalam tentang pendidikan seksualitas dalam sudut pandang psikologi.

\section{DaftarPustaka}

Abdullah Nasih Ulwan. 1998. Pendidikan Anak dalam Islam. Jakarta: Pustaka Amani,

Advocates for Youth. 2001. Toward a Sexually Healthy America.Washington, DC: Author. Retrieved November 20, 2003

Allgeier, E.R., and Allgeier, A.R. 1991 Sexuall Interactions (third edition) Massachusetts: D.C. Heath and Company

Anganthi, N.R.N., dan Lestari, S. 2007. Pola Komunikasi Seksualitas Pada Keluarga Muslim di Surakarta Laporan Penelitian Fundamental (tidak diterbitkan) Universitas Muhammadiyah Surakarta Surakarta.

Angela D. Weaver, et al. 2002. Sexual health education at school and at home: Attitudes and experiences of New Brunswick parents. University of New Brunswick. The Canadian Journal of Human Sexuality, 11 (1) 27-28

Bruess, C.E., \& Greenberg, J.S. 1991. Sex and Education: Theory and Practice. Califomia: Wadsworttr, 4th Edition.

Creswell. 2010. Research Design, Pendekatan Kualitatif, Kuantitatif dan Mixed. Pustaka Pelajar, Yogyakarta, Edisi Ketiga (Terjemahan). 
Fantasia, H.C. 2008 "Concept Analysis: Sexual Decision Making in Adolescence" Nursing Forum 43(2):80-90

Gerald S. 1999. The Effects of Sex Education on Teen Sexual Activity and Teen Pregnancy. The Journal of Political Economy, Vol. 107, No. 3. University of Chicago

Hurlock, EB. 1973. Adolencence Development. McGraw Hill, 4th Edition Laura Duberstein Lindberg. 2011. Consequences of sex education on teen and young adult sexual behaviors and outcomes. Journal of Adolescent Health. 51(4):332-8

Srianti, L. 2012. Jangan Biarkan Mereka Mati. Jaring Pena, Yogyakarta

Ma'ruf Zuraiq. 2008. Cara Mendidik Anak dan Mengatasi Problemnya, Nuansa Aulia, Bandung.

Marla E. Eisenberg, Sc.D., M.P.H. et al. 2007. Support for comprehensive sexuality education: perspectives from parents of school-age youth. Journal of Adolescent Health. University of Minnesota. 42(4):352-9

Nawita, M. 2013. Bunda Seks Itu Apa? Yrama Widya. Bandung

Papalia, Olds. R.D. 2009. Human Development. McGraw Hill

Payal Mahajan and Neeru Sharma. 2005 Parents attitude towards imparting sex education to their adolescent girls. Journal of Anthropologist. University of Jammu India. 7 (3), 198-199

Prihartini, Nuryoto, Aviatin. 2002. Hubungan antara komunikasi efektif tentang seksualitas dalam keluarga dengan sikap remaja awal terhadap pergaulan bebas antar lawan jenis. Jurnal Psikologi, (2), 124-139

PKBI. 1999. Laporan Evaluasi Kegiatan Kerjasama Plan Internasional Pacitan, Yogyakarta: Sahabat Remaja PKBI DIY

Singgih D. Gunarsa. 2012. Psikologi Remaja. Jakarta: BPK Gunung Mulia 
Lestari, S, Suparno \& Restu, Y. S. (2011). Identifikasi kebutuhan informasi seksualitas pada remaja. Jurnal Ilmiah Psikologi, 5 (2), 180-188

Lestari, S. 2010. Youth courtship sexual behavior, exposure to pornography, and parental sexual communication. Anima, 25

Lestari, S, Kadarwati, A \& Asyanti, S. 2008. Sikap remaja terhadap perilaku seks bebas: lebih dipengaruhi orangtua atau teman sebaya? Indigeneous, 10, 19-28.

Lestari, S \& Anganthi, N. R. N. 2008. Pola komunikasi seksualitas pada pasangan suami istri. Indigeneous, 10, 29-39.

Lestari, S. \& Prastiti, W. D. 2008 Makna menarche dan pengalaman psikologis yang menyertainya. Arkhe, 13 (1), 1-8.

Starkshall, 2007. Sex Education and Seksual Sosialization: Rules for Educator and Parents, Journal Proquest, 39 (2), 29-31

Sugiyono 2011. Metode Penelitian Pendidikan. Bandung: Alfabeta.

Nina, Surtiretna. 2001. Bimbingan Seks bagi Remaja. Bandung: Remaja Rosda Karya.

Sarwono, S.W. 2006. Psikologi Remaja. Jakarta: Raja Grafindo Persada.

Pohan, M. Drs. 2000. Masalah Anak dan Anak Bermasalah. Jakarta: Era Intermedia

Vicki Pittman, M.S., R.N., M.A. 2006. Comprehensive Sexuality Education or Abstinence-Only Education, Which Is More Effective? Journal of Research for Educational Leaders. Chicago State University. 2 (2) $60-91$ 